\title{
THE CONCEPT OF PEDAGOGICAL EDUCATION IN THE FAMILY IN THE WORKS OF ABDURAUF FITRAT
}

\author{
Shoira Abdujalilova \\ Candidate Of Pedagogical Sciences, Chirchik State Pedagogical Institute,Tashkent Region, Uzbekistan \\ Nurgul Sodiqova \\ Master Student, Chirchik State Pedagogical Institute, Tashkent Region, Uzbekistan
}

\section{ABSTRACT}

This article analyzes Abdurauf Fitrat's concept of pedagogical education in the family and draws methodological conclusions.

KEYWORDS: - Education, pedagogy, family, upbringing, knowledge, approach, theory, practice, experience, skill, knowledge.

\section{INTRODUCTION}

In the current period of new development of Uzbekistan, the development of pedagogical education, along with all other areas, plays a significant role. The Resolution of the President of the Republic of Uzbekistan dated February 23, 2020 "On measures to strengthen the training of teachers" sets the task "... to expand the scope of pedagogical research and increase their effectiveness [1]." In this regard, it is important to analyze the concept of pedagogical education in the family and master its content in the views of the first enlightened pedagogue, the first Uzbek professor Abdurauf Abdurahim oglu Fitrat (1886-1938).

\section{THE MAIN FINDINGS AND RESULTS}

Fitrat was an active modern pedagogue and reformist scholar of his time [2]. He is the owner of a "scientific heritage covering more than a dozen disciplines" [3. 28]. In this regard, in Fitrat's views, the issue of pedagogical education in the family is expressed in a special way. As mentioned above, in our research we understand the concept of "pedagogical education" in the form of imparting knowledge to the individual, educating him and directing him to the profession [See the Introduction section of the study]. Fitrat's understanding of the problem of pedagogical education in the family was formed in accordance with the social conditions, space and time requirements of the first quarter of the $\mathrm{XX}$ century, the pedagogical needs of his time. It is known that the renewal of social life and the reform of the education system were priorities in this period [4. 9]. In this regard, Fitrat's concept of the implementation of pedagogical education in the family is unique, in which the concept of 
CURRENT RESEARCH JOURNAL OF PHILOLOGICAL SCIENCES 2(6): 46-50,

May 2021 DOI: https://doi.org/10.37547/philological-crjps-02-06-10

ISSN 2767-3758

(C)2021 Master Journals

\section{Crossref do) 8 Google}

Accepted21 thJune, 2021 \& Published 27thJune, 2021

education-demand is exaggerated. Among the Jadid enlighteners, he posed the issue in a new way, and his approach to the issue was reflected in the 1914 pamphlet The Family or Family Management Procedures [5].

Fitrat's understanding of the implementation of pedagogical education in the family encompasses the following three important components:

1) Understanding the family phenomenon;

2) Know the educational responsibilities in the family;

3) To have an understanding of the basics of family upbringing.

These issues are within the framework of the concept of "education-demand", which reflects the individual approach of the scientist..

Understanding the family phenomenon. This issue is part of Fitrat's pedagogical education, which is one of the features of "Family Pedagogy". According to him, every adult should have a sufficient understanding of the family phenomenon and its role in human life. Because in time he can be engaged in education and upbringing in the family. Fitrat derives from such an approach and understands it as a pedagogical requirement that each individual understand the family phenomenon. In his first major scientific pamphlet, "Munozara", written in 1909, he noted that in the early twentieth century, the Bukhara Emirate had a population of 10 million and the capital, Bukhara, had a population of 70,000 , a "product of a strong family" [6. 49]. His second major treatise, "The Statement of an Indian Traveler", written in 1912, states that this population, which was the product of a strong family, was divided into Ulama (intellectuals), Umaro (from God) and citizens (population) in Bukhara Province [7. 98]. In this regard, according to Fitrat, the first issue in understanding the phenomenon of the family is to know the size of the population of the society in which the person lives and their social category. This issue was relevant to the life of Turkestan in the early twentieth century. Because the issues of development of social life and modernization of the education system depend on it. It is known that the family plays an important role in the size of the population, social categories and their development as individuals. Fitrat deeply understands this and recommends that the understanding of the family phenomenon begin with its reproductive function.

According to Fitrat, the second issue in understanding the family phenomenon has to do with knowing the social role of the family in an individual's life. In this regard, the educator thinks in the third major scientific pamphlet "Family or the order of family management" and believes that the family is a structure that unites the individual into a cultural category: "People didn't know the need to live as a community before they became a nation, they lived alone, like wild animals, and so they suffered under natural hardships. Eventually, people realized that they had to live as a community ... The formation of a family, or the foundation of family management, is the foundation of human culture" [5. 7]. In this sense, the family performs social functions that unite, cultivate and lead to happiness in the life of the individual and society. Fitrat's approach was socially and pedagogically important for the social life of the first quarter of the twentieth century, a hundred years ago. In this sense, he writes: "The family consists of husband, wife and children. A family is a group of people living in the same house under the leadership of one person ... The happiness and dignity of any nation, of course, depends on the internal discipline and harmony of this nation. Peace and harmony are based on the discipline of the families of this nation [5. 8]." This is to understand the social function of the family, and for this Fitrat recommends "reading books 
CURRENT RESEARCH JOURNAL OF PHILOLOGICAL SCIENCES 2(6): 46-50,

May 2021 DOI: https://doi.org/10.37547/philological-crjps-02-06-10

ISSN 2767-3758

(C)2021 Master Journals

\section{Crossref do) 8 Google}

Accepted21 thJune, 2021 \& Published 27thJune, 2021

written by Farang (European) scholars" [5. 8]. Thus, Fitrat's approach to the social issues of the family is in line with the Uzbek-Islamic and European approaches to the family [5.13-14].

According to the enlightened educator, the third issue in understanding the phenomenon of the family is to understand the importance of marriage. He discusses this issue in detail in the booklet "Family or Family Management". First of all, it should be noted that Fitrat, as a devout Muslim educator, accepts the basics of marriage as a perfect factor in Islam: "I am convinced that the most acceptable law for the happiness and importance of the family will be Islamic law." [5. 8]. At the same time, the educator recognizes the Belgians and the British as role models in the field of enlightenment, diligence and mobility of family members [5. 13].

According to Fitrat, marriage is determined by five important natural laws:

first, the family ensures the individual and social existence of man [5. 10]. It is the family that provides for individual needs, such as eating, drinking, breathing, dressing, having children, and being a community. These two categories of needs give rise to the vices of filth, loneliness, and depravity that form outside the family. This is why Fitrat points to marriage as one of the Sunnahs of the Prophet;

second, to build a family is to regulate the power of lust [5. 11]. The scientist educator considers prostitution, adultery, and illicit marriage to be the most heinous crimes, emphasizing that the regulation of lust, which is the basis for maintaining a person's permanence, takes place only through the family;

third, only the family ensures the survival of the nation [5. 13]. Fitrat points out here that the enlightened family system was the basis for the English population to reach 44 million and the Belgians to 7.5 million (of course, this data belongs to the early twentieth century Sh.A.);

fourth, the family is the foundation on which an individual is educated and brought up [5.14];

fifth, the family is the foundation for solving natural and social difficulties and problems [5. $15]$.

These five natural laws show the harm of not getting married.

Indeed, Fitrat's approach to understanding the family phenomenon is thus to comprehend these three issues.

Know the educational responsibilities in the family. This issue is one of the foundations of the concept of pedagogical education implemented in the family, according to which every adult family member should have sufficient knowledge of family education responsibilities. The first issue is that the husband and wife are mutually literate. Respect for women, respect for their rights, and the complementarity of husbands and wives in terms of knowledge are part of this literacy system [5. 33]. It is for this reason that Fitrat strongly criticizes the fact that in his time women were completely excluded from knowledge and activism. "Women in our country," he writes, "are being abused and tortured every minute. We Turkestans think that our women are beyond the scope of humanity ... We do not consider them worthy of blessing, fairness and compassion. [5. 33]" Although this is true of the social life of Turkestan in the early twentieth century, it reflects Fitrat's approach to the equal participation of women in family education. Because, according to the scholar, "A person receives his first upbringing in his mother's arms, and it is inevitable that the first upbringing is the most important of upbringing; its influence is firmly entrenched in human nature." [5. 34] In this regard, women are required to be equally literate in family education with the rest. 
CURRENT RESEARCH JOURNAL OF PHILOLOGICAL SCIENCES 2(6): 46-50,

May 2021 DOI: https://doi.org/10.37547/philological-crjps-02-06-10

ISSN 2767-3758

(C)2021 Master Journals

\section{Crossref do) 8 Google}

Accepted21 thJune, 2021 \& Published 27thJune, 2021

According to the enlightened educator, the second issue in knowing the educational tasks in the family is to create an educational environment. According to him, parents and older members of the family should be able to create an environment in the family to carry out education and upbringing at the expected level. When a specific primary pedagogical environment is created in the family, that is, the purpose of teaching, certain conditions and purposeful action, then it is possible to establish pedagogical education. Fitrat sees this as one of the main issues and sees its foundation in the relationship between husband and wife. According to the scientist, if the relationship between husband and wife, which is the foundation of the family, is built on the principles of morality, spirituality and religion, it will be possible to create the expected learning environment in the family. In this regard, he said, based on their circumstances, the relationship between husband and wife should be "based on the rules of the Qur'an [5. 35].' According to modern scholars, one of the firm and reliable foundations of the relationship between husband and wife is described in the Qur'an [8]. This is because the Qur'an defines the duties, duties, duties and responsibilities of husband, wife and family members in an equal and reasonable manner. Fitrat sees the basis for this in Love: "Our modern (early twentieth century - Sh.A.) scientists and sages have come to the conclusion that all particles and descendants in the universe cannot coexist without love. The relationship between humans and animals is also based on the principle of love. Even if the relationship between husband and wife does not reach the level of love, it is necessary to find a way so that they do not hate each other" [5. 35].

Thus, Fitrat believes that the key to creating an educational environment in the family is in a loving (mutual understanding) relationship between husband and wife. Such an approach seems primitive at first glance. In fact, the pedagogical scientist focused on the psychological aspect of the issue in accordance with his time. It is no secret that even today, when the family's material and spiritual wellbeing is high, the weakness of the educational environment, the persistence of "satiety" and the fact that family education is often ineffective are the result of husband-wife relationships.

The third issue in knowing the educational responsibilities in the family is responsibility. According to this approach of Fitrat, adults in the father, mother and family must feel responsible for the education (learning) of the younger generation. To do this, it is necessary to follow the rules of family, childbearing and morality. In particular, Fitrat writes: "There are people in our country who, in the face of their false opinions and misconceptions, abandon their wives and children ... In fact, Islam does not accept their actions, but applies them." [5. 38] or: "Another bad habit in our country is that we deprive our girls of the privilege of education. That is why our women have no knowledge of faith, prayer or Islamic morality" [5. 38]. Or, "need to know that moral qualities such as religion and honor are necessary not only for the happiness and discipline of a family, but also for the happiness and stability of an entire country. Today, European nations, relying on such moral and natural forces, have raised their science and art to an astonishing level" [5.41].

All of this makes it necessary for parents, mothers, and older members of the family to have family, parenting, and moral values, and as a result, they have a responsibility for the education that takes place in the family.

\section{Conclusion}

In short, Fitrat points to the mutual literacy of the couple, the creation of a learning environment, and the responsibility of those 
CURRENT RESEARCH JOURNAL OF PHILOLOGICAL SCIENCES 2(6): 46-50,

May 2021 DOI: https://doi.org/10.37547/philological-crjps-02-06-10

ISSN 2767-3758

(C)2021 Master Journals

Crossref dof 81 Google

Accepted21 thJune, $2021 \&$ Published 27thJune, 2021

involved in family education as a level of knowledge of the educational tasks performed in the family. These are pedagogical, psychological and social factors.

\section{REFERENCES}

1. The newspaper "People's Word" February 24,2020 . See the Introduction to our study on the methodological analysis of this issue, and we will return to this issue later in our study.

2. Boltaboev H. Uzbek literature of the early twentieth century and the scientific heritage of Abdurauf Fitrat. DDA. Tashkent: 1996. Abdujalilova Sh. Abdurauf Fitrat's views on family upbringing. NDA. Tashkent: 2002. Axrorova D. Enlightenment-pedagogical views of Abdurauf Fitrat. NDA. Tashkent: 1998, G'aniev I. Fine arts in the works of Abdurauf Fitrat. DDA. Tashkent: 2007, etc.

3. Boltaboev H. Nature and the spirituality of independence. // Abdurauf Fitrat. Selected works. Volume 1 Tashkent: "Spirituality". 2000. -p.28.

4. Qosimov B. National Awakening: Courage, Devotion, Perseverance. Tashkent: "Spirituality". 2002. -p.9.

5. Fitrat A. Family. Tashkent: "Spirituality". 1998.

6. Fitrat A. Discussion. // Selected works. Volume 1 Tashkent: "Spirituality". 2000. p.49.

7. Fitrat A. Statement of an Indian tourist. // This source. -p. 98.

8. Anna Mare Shemmel. John is my soul. Tashkent: "New Age Generation”. 2002.
9. Abdujalilova Sh. Abdurauf Fitrat's views on family upbringing. NDA. Tashkent: 2002.

10. Axrorova D. Enlightenment-pedagogical views of Abdurauf Fitrat. NDA. Tashkent: 1998.

11. G'aniev I. Fine arts in the works of Abdurauf Fitrat. DDA. Tashkent: 2007, etc. 